\title{
Prevalence of islet cell antibodies, insulin antibodies and hyperglycaemia in 2291 schoolchildren
}

 \\ ${ }^{1}$ Centre Assistència Primaria, Institut Català de la Salut, Lleida, and \\ ${ }^{2}$ Endocrinology and Diabetes Unit, Hospital Clinic, University of Barcelona, Spain
}

Summary. Islet cell antibodies, insulin antibodies and hyperglycaemia were investigated in 2291 healthy schoolchildren. Eight of the subjects had islet cell antibodies and eight had insulin antibodies. However, no schoolchild who was positive for islet cell antibodies also had insulin antibodies present. Hyperglycaemia was observed in five children but nei- ther islet cell antibodies nor insulin antibodies could be detected in the sera from these particular subjects.

Key words: Islet cell antibodies, insulin antibodies, hyperglycaemia, schoolchildren, pre-Type 1 (insulin-dependent) diabetes.
During the last few years, several reports have described the presence of islet cell antibodies (ICA-IgG) [1-3] and insulin autoantibodies (IAA) [2-4] in the serum of first degree relatives of patients affected with Type 1 (insulin-dependent) diabetes mellitus.

Current studies suggest that there exists a latent asymptomatic period before the development of overt Type 1 diabetes mellitus in which the presence of autoantibodies may already be detected $[3,5,6]$. Moreover, it has been suggested that ICA-IgG and IAA may be good markers for the autoimmune destruction of the pancreatic B cells, often culminating in clinical Type 1 diabetes mellitus $[2,6]$.

The aim of this study was to evaluate the prevalence of hyperglycaemia, ICA-IgG and IAA in a large population of Spanish schoolchildren.

\section{Subjects and methods}

We studied 2291 healthy Spanish schoolchildren (1266 males, 1025 females) aged between 14 and 17 years, from eight schools (27\%) from private schools and $73 \%$ from public schools) in Lleida, Spain. All had parental consent to participate in the study, which was approved by the Catalan Committee for the Study of Diabetes.

At basal state, a venous blood sample was obtained, for the determination of blood glucose, IAA and ICA-IgG.

Blood glucose was analysed using a wipe-off strip (BM Test BG, Boehringer-Mannheim, Mannheim, FRG) adapted to be read using a reflectance meter (Reflolux, Boehringer-Mannheim). When the screening value was higher than $6.6 \mathrm{mmol} / 1$, the plasma was reanalysed twice using the glucose-oxidase method adapted to an Autoanalyser II (Beckman Instruments, Fullerton, Calif., USA).
IAA were measured using a modification of the method described by Kurtz et al. [7]. Briefly, serum was incubated for $24 \mathrm{~h}$ at $4{ }^{\circ} \mathrm{C}$, in the presence of ${ }^{125}$ mono-iodinated labelled human insulin, $0.04 \mathrm{mmol} / \mathrm{l}$ phosphate buffer $(\mathrm{pH} 7.4), 0.5 \%(\mathrm{w} / \mathrm{v})$ bovine serum albumin. Free labelled insulin was precipitated by adding activated charcoal dextran and centrifuged $1300 \mathrm{~g}$ for $15 \mathrm{~min}$ at $4^{\circ} \mathrm{C}$. Both the precipitate and the supernatant were examined for radioactive content. Binding results are expressed in percentages calculated as follows:

$\%$ bound $=\frac{\mathrm{CPM} \text { of sample- CPM non-specific binding }}{\text { total CPM in the assay }}$

The intra- and interassay coefficients of variation were $11.2 \%$ and $34.0 \%$, respectively, and the sensibility was $0.9 \%$.

ICA-IgG were determined by the double indirect immunofluorescence technique (fluorescein rhodamine) using cryostat sections of a human donor pancreas (group 0 ) with undiluted serum obtained from the subjects. Results are expressed as J.D.F. units, in accordance with the Second International Workshop on the Standardisation of ICA [8].

\section{Results}

\section{Blood glucose}

Five schoolchildren $(0.22 \%$ of the total population) showed plasma glucose values higher than $6.6 \mathrm{mmol} / 1$ in three serial determinations; subsequently these 5 subjects were subjected to an oral glucose tolerance test $(1.75 \mathrm{~g} / \mathrm{kg}$ body weight). All of them showed a normal glucose tolerance by whatever criteria; and had a normal body mass index. In addition, in none of the sera from these subjects, could the presence of IAA or ICA-IgG be detected (Table 1). A family history of diabetes mellitus was positive in five cases (Table 2). 
Table 1. Schoolchildren with hyperglycaemia, insulin and islet cell antibodies

\begin{tabular}{|c|c|c|c|c|c|c|}
\hline & 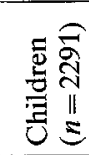 & 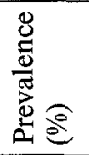 & 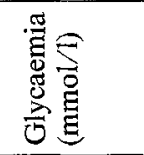 & 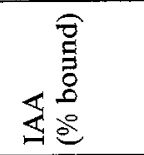 & 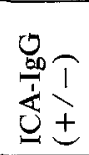 & 芯士 \\
\hline $\begin{array}{l}\text { Hyper- } \\
\text { glycaemia } \\
(>6.6 \mathrm{mmol} / 1)\end{array}$ & 5 & 0.22 & $6.90 \pm 0.19$ & $0.89 \pm 0.33$ & - & - \\
\hline $\begin{array}{l}\text { IAA } \\
(>2.7 \%)\end{array}$ & 8 & 0.35 & $4.93 \pm 0.23$ & $5.19 \pm 2.24$ & - & - \\
\hline $\begin{array}{l}\text { ICA-IgG } \\
\text { positive }\end{array}$ & 8 & 0.35 & $4.65 \pm 0.61$ & $0.66 \pm 0.24$ & + & - \\
\hline GCA positive & 15 & 0.65 & $5.11 \pm 0.52$ & $0.87 \pm 0.27$ & - & + \\
\hline
\end{tabular}

Glucose and IAA values are mean $\pm \mathrm{SD}$; IAA, insulin autoantibodies. ICA-IgG positive ( + , presence of islet cell antibodies to the $B$ cell. GCA, positive $(+)$ presence of antibodies against glucagonproducing cell

Table 2. Family history of diabetes mellitus in schoolchildren with hyperglycaemia, insulin and islet cell autoantibodies

\begin{tabular}{lllll}
\hline & Absent & \multicolumn{2}{l}{ Present } & \\
\cline { 2 - 5 } & & $\begin{array}{l}\text { Type 1 } \\
\text { (insulin- } \\
\text { dependent) }\end{array}$ & $\begin{array}{l}\text { Type 2 } \\
\text { (non-insulin- } \\
\text { dependent) }\end{array}$ & $\begin{array}{l}\text { Type 2 } \\
\text { (insulin- } \\
\text { treated) }\end{array}$ \\
\hline $\begin{array}{l}\text { Hyperglycaemia } \\
\begin{array}{l}>6.6 \text { mmol/1 } \\
(n=5)\end{array}\end{array}$ & $1(20 \%)$ & - & $4(80 \%)$ & - \\
$\begin{array}{l}\text { IAA>2.7\% } \\
(n=8)\end{array}$ & $4(50 \%)$ & - & $2(25 \%)$ & $2(25 \%)$ \\
$\begin{array}{l}\text { ICA-IgG } \\
\text { positive } \\
(n=8)\end{array}$ & $6(76 \%)$ & $1(12 \%)$ & - & $1(12 \%)$ \\
$\begin{array}{l}\text { GCA positive } \\
(n=15)\end{array}$ & $8(53 \%)$ & - & $4(26 \%)$ & $3(21 \%)$ \\
\hline
\end{tabular}

The percent of observations is shown in parentheses

\section{Insulin-autoantibodies}

The mean binding of labelled human insulin by $100 \mu 1$ of serum from the 2291 schoolchildren was $1.01 \pm$ $0.52 \%$ (mean $\pm \mathrm{SD}$ ). Values above 3.29 standard deviations of the mean value, i. e. above $2.73 \%$ were considered positive for IAA if they displayed values above $2.73 \%$ in three serial determinations.

These criteria were met in 8 children $(0.35 \%$ of the total population) (Table 1), none of whom had previously received insulin injections. Moreover, no child found positive for IAA showed the presence of ICA$\mathrm{IgG}$, or a positive family history of Type 1 diabetes mellitus (Table 2).

\section{Islet cell antibodies}

The prevalence of ICA-IgG among the schoolchildren was $0.35 \%$ ( 8 of the 2291 ) (Table 1 ). In five children, the ICA-IgG showed 5 J.D.F. units and in the remaining three, $10 \mathrm{~J} . D . F$. units. None of them were positive for complement fixing islet cell antibodies (CF-ICA).

Furthermore, in 15 children $(0.65 \%)$ the presence of antibodies against glucagon-producing cell (GCA) was observed (Table 1). None of them (ICA-IgG and GCA) showed values of blood glucose higher than 6.6 $\mathrm{mmol} / \mathrm{l}$. Six of the eight ICA-IgG positive children did not have a positive family history of diabetes mellitus (Table 2). Of the remaining two, one had a grandfather with insulin-treated diabetes mellitus and the other a first cousin with Type 1 diabetes.

\section{Discussion}

ICA-IgG and IAA have been found in individuals many years before the onset of clinical Type 1 diabetes mellitus and may serve as markers for the B-cell destructive process $[2,3,5,6]$. There is very little information available about the presence of these antibodies in unselected populations of healthy individuals.

In the present study, we investigated the presence of ICA-IgG and IAA in 2291 schoolchildren from Lleida (Catalonia, Spain), a city of 111,400 residents. Our sample was of an average age and proportionally represented the public and private schools of the area.

We identified five subjects with basal hyperglycaemia without the presence of serological markers of diabetes autoimmunity, but with a high frequency $(80 \%)$ of familial Type 2 (non-insulin-dependent) diabetes mellitus. However, all of them had a normal oral glucose tolerance test.

The prevalence of IAA in this school population is in agreement with the observation of McEvoy [5] in the normal population, but it is lower than the value reported by Atkinson in a study of 292 schoolchildren [2]. It could be argued that most of the differences in the prevalence of IAA in normal populations might be related to the variations in the insulin binding assay [4]. On the other hand, we believe that differences in the age distribution of the cohort studied might also explain some of the differences between the findings of Atkinson et al. [2] and ours as supported by the report of McEvoy et al. [5].

In contrast to observations of significant associations between ICA-IgG and IAA in diabetic patients at diagnosis, i.e. before insulin therapy, and in the normal population [2], we have observed a lack of association between these two serological parameters.

The presence of ICA-IgG was observed in $0.35 \%$ of the pupils. Such a frequency is similar to that reported by others $[1,10]$. In monozygotic twins [9] and first-degree relatives of Type 2 diabetic patients, the frequency of ICA-IgG positivity seems to be higher than in our cohort of unselected schoolchildren. In this study, only two subjects had first degree relatives with Type 1 diabetes. 
Whilst it can be expected that ICA-IgG and IAA in youngsters may be transient, the reported increased risk for the development of Type 1 diabetes mellitus in subjects positive for ICA-IgG and for IAA suggests the necessity for metabolic and immunologic follow-up investigations in the normoglycaemic schoolchildren positive for these hypothetical immunologic markers for Type 1 diabetes as identified in this study.

Acknowledgements. This study was greatly facilitated by M. Marti, L. Porta, M.Serra, T.Vidal and A. Alló (Lleida) and the technical assistance of M. Guillen and J. Mendola (Barcelona). We are deeply indebted to R. Pujol, Department of Immunology, Middlesex Hospital Medical School, London and Professor E. Vilardell (Barcelona) for their continuing cooperation and stimulating suggestions. We are also grateful to the Department de Sanitat and Ensenyament de la Generalitat de Catalunya. This work was supported by the Comissió Interdepartamental d'Investigació i Ciència (CIRIT) and Comision Asesora Investigacion y Ciencia (CAYCIT).

\section{References}

1. Betterle C, Zanette F, Pedini B, Presotto F, Rapp LB, Monciotti CM, Rigon F (1984) Clinical and subclinical autoimmune manifestations in Type 1 (insulin-dependent) diabetic patients and their first-degree relatives. Diabetologia 26: 431-436

2. Atkinson MA, Maclaren NK, Riley WJ, Winter WE, Fisk OD, Spillar RP (1986) Are insulin autoantibodies markers for insulindependent Diabetes Mellitus? Diabetes 35: 894-898

3. Srikanta S, Rickey AT, McCulloch DK, Soeldner JS, Eisenbarth GS, Palmer JP (1986) Autoimmunity to insulin, beta cell dysfunc- tion and development of insulin-dependent diabetes mellitus. Diabetes 35: 139-142

4. Wilkin T, Armitage M, Casey C, Pyke DA, Hoskins PJ, Rodier M, Diaz JL, Leslie RDG (1985) Value of insulin autoantibodies as serum markers for insulin-dependent diabetes mellitus. Lancet II: $480-484$

5. McEvoy RC, Witt ME, Ginsberg-Fellner F, Rubinstein P (1986) Anti-insulin antibodies in children with Type 1 diabetes mellitus. Diabetes 35: 634-641

6. Spencer KM, Dean BM, Lister J, Bottazzo GF (1984) Fluctuating islet-cell autoimmunity in unaffected relatives of patients with insulin-dependent diabetes. Lancet I: 764-766

7. Kurtz AB, Matthews JA, Mustaffa BE, Dagget PR, Nabarro JDN (1980) Decrease of antibodies to insulin proinsulin and contaminating hormones after changing treatment from conventional beef to purified pork insulin. Diabetologia 18: 147-150

8. Bonifacio E, Dawkins RL, Lernmark A (1987) Immunology and Diabetes Workshop: Report of the Second International Workshop on the Standardisation of Cytoplasmic Islet Cell Antibodies. Diabetologia 30:273

9. Barnett AH, Eff C, Leslie RDG, Pyke DA (1981) Diabetes in identical twins. Diabetologia 20: 87-93

10. Notsu K, Dka N, Note S, Nabeya N, Kuno S, Sakurami T (1985) Islet cell antibodies in the Japanese population and subjects with Type 1 (insulin-dependent) diabetes. Diabetologia 28: 660-662

Received: 6 April 1987

and in revised form: 29 July 1987

Dr. Ramon Gomis

Hospital Clinic

Endocrinology and Diabetes Unit

Villarroel, 170

E-08036 Barcelona

Spain 